Canadian Journal of Higher Education

Revue canadienne d'enseignement supérieur

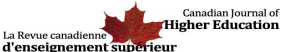

\title{
Book review of "Rewiring Education: How Technology Can Unlock Every Student's Potential"
}

\section{Pamela Anne Walsh}

Volume 48, Number 3, 2018

URI: https://id.erudit.org/iderudit/1057135ar

DOI: https://doi.org/10.7202/1057135ar

See table of contents

Publisher(s)

Canadian Society for the Study of Higher Education

ISSN

2293-6602 (digital)

Explore this journal

Cite this review

Walsh, P. (2018). Review of [Book review of "Rewiring Education: How

Technology Can Unlock Every Student's Potential"]. Canadian Journal of Higher

Education / Revue canadienne d'enseignement supérieur, 48(3), 182-184.

https://doi.org/10.7202/1057135ar viewed online.

https://apropos.erudit.org/en/users/policy-on-use/ 


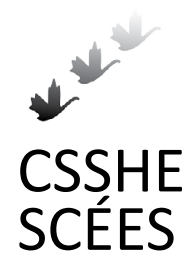

Canadian Journal of Higher Education Revue canadienne d'enseignement supérieur

Volume 48, No. 3, 2018, pages $182-184$

\section{Book Review / Compte rendu}

Couch, John, and Towne, Jason (2018). Rewiring Education: How Technology Can Unlock Every Student's Potential. Dallas, TX: BenBella Books. Pages: 243. Price: 27.27 CAD (hardcover).

Reviewed by Pamela Walsh, Associate Professor, Distance Education, Athabasca University

This book is about the grade school education system in the United States, kindergarten to grade 12, its flaws, and how the use of currently available technologies in the classroom can revolutionize teaching and learning. It argues that the current educational system was designed to teach students during the industrial era and was influenced by Frederick Taylor's theory of management, including the importance of efficiency and the standardization of practices. The book's main criticism of the current system relates to its focus on the acquisition of information, mainly through memorization, instead of the fostering of critical thinking, creativity, and problem-solving in individual students through a personalized approach to learning. It maintains that learning has been about what to think instead of how to think. The authors create their arguments through personal reflections, experiences, and observations, as well as conversations and interviews with professionals in the field of education and learning. To illustrate and support their claims, the authors draw upon research findings reported in books, reports, magazines and, to a lesser extent, scholarly sources of information that include academic journals.

The book is divided into an introduction and 15 thematic chapters, each opening with a quotation about education by relatively well-known and well-regarded individuals such as John Dewey, Maria Montessori, William Yeats, and Steve Jobs. These quotations are related to the main theme of their respective chapters. Each chapter has a one-word name such as "Rewiring," "Code," "Teaching," "Technology," and "Transformative," and includes anecdotes that help to illustrate the authors' main points or arguments which helps to make the book's narrative accessible and interesting to a wider audience of readers. Additionally, every chapter introduces the reader to at least one educational practitioner, researcher, thinker, or visionary who has provided insights into - or otherwise contributed to - education and learning. 
In the introduction and Chapter 1, "Rewiring," the book presents the problems with the current system of grade school education in the United States and contends that past "repair" and "replace" efforts have not been successful. This chapter cites the work of John Dewey, the educational theorist and reformist who advocated that individuals learn best through hands-on interactive learning, to help support its claims. The chapter ends with a call to "rewire" the education system by moving away from passive models of learning to more active models, and through the use of research and current technology to personalize each student's learning experiences.

Chapters 3 to 5 focus on student potential, motivation, and learning and further elaborate on the problems in the education system. The authors draw upon academic studies, and personal and professional anecdotes about topics such as student engagement, collaborative learning, motivation and self-determination, and the role that pre-existing experience plays in learning. The treatment of motivation in this section of the book is particularly compelling. The book contends that the most important factor in achieving success, both inside and outside of the education system, is motivation, which, along with preservation, is a prerequisite to learning. Arguments include the problems with standardized tests and memorization versus understanding. The authors state, with conviction, that personalized learning is the backbone of successful teaching and learning.

Throughout the book, and in particular in chapters $7,8,9,12$, and 13, the authors share stories about Apple's work with schools and contributions to the educational community. At the centre of many of these stories is the late Steve Jobs and his leadership and passion for education and learning. In Chapter 7, "Challenges," the book describes Jobs' efforts in the early 1980 os to provide access to computers for hundreds of thousands of students. This chapter also describes Apple's first major educational research project on students and technology, launched in 1985. This research study, Apple Classrooms of Tomorrow (ACOT), was a collaboration between public schools, universities, research agencies, and Apple. The book provides the findings of this interesting study which have also been presented in reports (Ringstaff, Yocam, \& Marsh, 1985) and at least one academic journal (Dwyer, 1994).

The last section of this book (chapters 14 and 15), is devoted to technology and its potential to transform learning. This section references and briefly describes frameworks and models for the effective integration of technology in the classroom, including the work of Lee Shulman, and Koehler, Mishra and Cain (2013). It provides a list and brief explanation of technologies that show the greatest potential to transform learning; these include artificial intelligence and adaptive learning. The book describes other technologies such as augmented reality as futuristic but holding promise for improving learning. Finally, the book closes with a call to action issued to educational leaders and government decision makers.

This book is not an academic treatise, but it does bring together a good argument for a reform of the $\mathrm{K}$ to 12 educational systems with reference to seminal and other scholarly works, the authors' personal experiences, the accomplishments of gifted educators, and anecdotes about talented, interesting, and successful people in the educational arena. Readers may be skeptical about the book's motives in including frequent references to Apple Inc. However, the book, in part, is an unabashed tribute to the achievements of Apple and its two co-founders. This book is accessible to a wide variety of readers; while 
it references pedagogical themes, for example, these are narrated in easy-to-understand language. Although this book is about teaching, learning, and technology, many of the concepts and ideas that are presented have long been associated with adult learning, such as the importance of the learner experience, motivation to learn, and problem-centred learning. While situated in the American context, the authors' ideas and suggestions may be of interest to other jurisdictions. I recommend this book to teachers, professors, educational leaders, parents, and members of the public who may be interested in educational reform and the potential of technology to enhance learning.

\section{References}

Dwyer, D. (1994). Apple classrooms of tomorrow: What we've learned. Educational Leadership, 51(7), 4-10. Retrieved from http://www.ascd.org/publications/educationalleadership/apr94/vol51/numo7/Apple-Classrooms-of-Tomorrow@-What-We'veLearned.aspx

Koehler, M. J., Mishra, P., \& Cain, W. C. (2013). What is technological pedagogical content knowledge (TPACK)? Journal of Education, 193(3), 13-19. https://doi. org/10.1177/002205741319300303

Ringstaff, C., Yocam, K., \& Marsh, J. (1985). Integrating technology into classroom instruction: An assessment of the impact of the ACOT teacher development center project (ACOT Report No. 22). Retrieved from https://www.apple.com/euro/pdfs/acotlibrary/ rpt22.pdf 